\title{
INTERACTION BETWEEN MINISTERS AND MEMBERS OF THE CONGREGATIONS IN THE DRCA FS (NGKA VS $)^{1}$
}

\author{
Khamadi Joseph Pali ${ }^{2}$ \\ Practical and Missional Theology \\ University of the Free State
}

\begin{abstract}
Recent studies on the DRCA FS indicate that there is a decrease in the positive interaction between ministers and the members of their congregations. This is manifested in the way in which the ministers describe the members of their congregations or the way in which congregation members describe the leadership of their ministers. This decrease in interaction between ministers and the members of their congregations is reflected in the increase in conflict situations characterised by disagreements, litigations and violence. This article raises the following research question: What are the dynamics of the interaction between ministers and members of the congregations in the DRCA FS? This article aims to analyse the interaction between ministers and members of the congregations in the DRCA FS.
\end{abstract}

Keywords: ministers; lay people; followers; leadership; overrating; underrating; DRCA FS; NGKA VS

\section{Introduction}

A general study of leadership literature reveals that there is a growing interest in the study and production of leadership literature (Bligh and Meindl 2005:11). For a long time, this increased interest was mainly from a leader perspective. However, contemporary leadership literature is developing an interest in the role of the follower in the leadership both within and beyond organisations. Consequently, this interest in followership has influenced the conventional approach and understanding of leadership to shift from being leader-centric to leadership as a mutual relationship of influence. This shift has greatly impacted on the way in which leadership should relate with their followers in the leadership process.

This article poses the following research question: What are the dynamics of the interaction between ministers and members of the congregations in the DRCA FS? This article aims to analyse the interaction between ministers and members of the congregations in the DRCA FS. In the DRCA FS leadership in congregations refers to the minister, the deacons and the elders who form a church council. This article will mainly emphasise the minister rather than the deacon and the elder. The followers are

The Afrikaans name of the DRCA FS is Die Nederduitse Gereformeerde Kerk in Afrika, Vrystaat (NGKA VS).

2 Dr KJ Pali, Lecturer in the Department of Practical and Missional Theology at the Faculty of Theology and Religion, University of the Free State, Bloemfontein. He is also an ordained minister in the DRCA FS. Contact email: palikj@ufs.ac.za. This article is written with the support of an NRF-FRF sabbatical postdoctoral grant (reference: NFSG170904261632, grant no.: 112203). 
the congregation members who can also be called the laity or the lay people in the congregations. The objectives of this study are:

- $\quad$ To establish what kind of relationship exists between ministers and members of the congregations in the DRCA FS.

- To analyse how ministers and congregation members describe each other in the congregations of the DRCA FS.

- To explain the conceptual understanding of leadership and its role in the congregations of the DRCA FS.

- To investigate how the interaction between the minister and the laity impacts on the integrity of the ministry in the congregations of the DRCA FS.

This study is essential, because the shift in leadership studies has greatly affected the way in which leadership functions in many sectors of society and in congregations in particular. Christianity is essentially about the practice of followership (Huizing 2011:58). This implies that in the Christian context leaders are first followers of Christ before they are leaders. Leadership is a delegated responsibility to help Christians become effective followers of Christ. Hence, training the laity to be effective followers in leadership and prepare them for leadership in the future is essential. For a long time, leadership practice has ignored the role of followers in leadership, despite the reformation's attempts to revive the role of the laity in the church. This article uses the empirical data from Pali (2016). ${ }^{3}$

\section{Definition of spiritual leadership}

A definition of leadership varies depending on the context in which it is defined. In the Christian context, especially in congregations, leadership is spiritual, because it is based on the Triune God. Spiritual leadership is leadership that strives to lead in God's way, regardless of where it serves Him (Blackaby and Blackaby 2011:33). Gangel (2006:591, $592,595)$ defines spiritual leadership as leadership that focuses on the development of relationships with people of a Christian institution or body of Christ, enabling them to formulate and achieve the divine goals that meet their real needs. According to Gangel, spiritual leadership serves God by prioritising the needs of others, not those of leaders. It uses strategies that embrace, build, and empower others. It works according to God's agenda to develop and inspire people to move from where they are to where they should be (Blackaby and Blackaby 2011:34,144). Therefore, the leadership of ministers and lay leaders in congregations is spiritual when it is based on the Triune God and strives to fulfil the will of the Triune God.

\subsection{Shift in leadership approaches}

Drawing on leadership studies in the social sciences, various approaches have been used to practise leadership in numerous spheres of society. The trait approach is the first

\footnotetext{
Pali (2016) is a PhD dissertation submitted jointly to the University of the Free State, Bloemfontein, and Vrije Universiteit, Amsterdam, in 2016. This empirical study is entitled: Leadership and transformation in the African church: A practical theological study of one denomination. Chapter 1 discusses the theory on empirical methods, while Chapters 2 and 3 discuss the empirical data. The quantitative data in this $\mathrm{PhD}$ study consists of a Minister Survey (MS) and a Congregation Survey (CS). The qualitative data consists of Individual Interviews (II) with ministers, and Focus-Group Interviews with congregation members (FGI).
} 
leadership approach that developed in the 1930s to 1940s (Yukl 2002:12; Bass and Bass 2008:50). This approach assumes that some people are natural born leaders endowed with special traits such as physical, mental, and social capabilities that differentiate them from their followers (Yukl 2002:11).

The second approach is the behavioural leadership approach (Northouse 2012:5) that originated in the 1950s. This approach compares the behaviour of effective leaders with that of ineffective leaders. The behaviour of an effective leader is classified as interpersonal relationships or task-oriented relationships (Steers et al. 1996:168; Hellriegel et al. 1998:308). The interpersonal relationships of leaders involve a concern for subordinates, being friendly and supportive, mutual trust between leaders and followers, co-operation, and settling disputes. The task-oriented relationships of leaders focus on the quality and quantity of work accomplished. This involves aspects such as planning and scheduling, co-ordinating, and providing the necessary assistance.

The third approach is the contingency leadership approach of the 1960s. According to Steers et al. (1996:169-175), this approach focuses on certain variables that make leadership behaviours and characteristics effective in a given situation. It believes that interaction between leaders, followers, and the situation in which leadership takes place, can contribute to the leader's effectiveness.

The fourth approach is the emerging leadership approach that originated in the early 1970s to the present (Grint 2011:10). Steers et al. (1996:179-181) argue that this approach resorts under three categories. It is a leader-member exchange theory that focuses on a reciprocal influence process within leader-follower dyads. It is a charismatic theory about leadership acting in an unconventional manner in order to achieve a vision, in which case the leader is usually self-sacrificial, takes personal risks, and uses personal persuasion to gain the followers' commitment to a new cause. Thirdly, it resorts under transformational theory, which is concerned with the deliberate intention to effect changes in the followers' motive patterns, elevating followers to their better selves, and motivating them by means of high order needs such as achievement and selfactualisation.

The fifth approach, which is still developing in the $21^{\text {st }}$ century, is known as the dispersed leadership approach (Gordon 2010:262). It views leadership as a collective social process emerging through the interactions of multiple actors such as a leader's traits, situation, and behaviour (Bolden 2011:251). It views leadership as a group activity that operates through and within relationships between the leader and the follower (Bolden 2011:251). This approach supports power-sharing between leaders and followers and the sharing of leadership skills and responsibilities throughout an organisation. Examples of leadership forms in this approach are super-leadership, selfleadership, leadership as a process, and distributed leadership (Gordon 2010:262).

Gordon (2011:164-165, 167) describes the first four approaches as reflecting traditional accounts of leadership. He claims that traditional accounts of leadership encourage adherence to the orthodox approach to leadership that is characterised by hierarchy and control. He also mentions that they stress the historical leader-follower differentiation of power to the concept of leadership. Gordon $(2011: 164-165,167)$ states that this occurs in a context of accentuation of the leader's voice at the expense of undermining the voice of the followers. The followers who try to resist the status quo are labelled as resistant, dysfunctional, and illegitimate. Furthermore, according to Burak 
and Bashshur (2013:1), the weakness of these orthodox approaches to leadership is that followers are treated as the passive recipients of leader influence and leadership outcomes. The flow of influence of leadership is unilateral, that is, from a leader to a follower. In short, Gordon $(2011: 164-165,167)$ reiterates that these traditional leadership theories promote dominance and differentiation that are so deeply embedded in organisations and social structures that they seem natural.

However, the essential point about the fifth approach to leadership is its emphasis on the relationship and mutual influence between a leader and a follower. In Gordon's terms (2011:164-165, 167), this fifth leadership approach encourages a shift towards the decentralisation of leadership skills, power, and responsibility in an organisation. In this leadership approach, leadership is achieved not only by an extraordinary person, but also by many people in the context of sharing power, collaborating to eliminate differentiation, and giving a voice to the follower. The fifth approach implies that the leadership approach has shifted from the leader to the relationship in leadership practice.

In the light of the above, contemporary leadership studies, including those in Christian religion, have shifted from viewing leadership as a specialised role due to special qualities or skills, to a shared process in a social system where everyone has the potential to exercise leadership (Yukl 2002:3, 4). Another shift is that from the leader to a quality relationship of influence between the leader and the follower. According to Christian theologian Wright (2009:3), in the context of leadership in congregations, leadership as a quality relationship of influence between leaders and their followers has shifted the locus of leadership from the minister as a leader to a mutual and quality relationship between ministers and laity. For Wright, the consequence of this shift is that the burden of leadership has shifted from the minister to both the minister and the laity who have the opportunity to exchange their roles in leadership. In other words, depending on the context and need, a minister may adopt the role of a follower and a follower may adopt the role of a leader. The shift towards leadership as a quality relationship of influence implies sharing responsibilities. This involves the decentralisation of leadership power in the congregation, as both the minister and the laity have the potential to influence each other. Furthermore, this shift in leadership implies that the issue of hierarchy, control, or emphasis on differentiation between ministers and their laity is no longer prominent, as sharing and equality in the practice of leadership are highlighted as significant values in leadership (Wright 2009:3).

\subsection{How do we relate this shift in leadership with some of the leadership perspectives in the Bible?}

From a Biblical perspective, the shift of leadership practice towards a quality relationship of influence is not new. In the New Testament era churches often had a bishop (1 Tim $3: 1,2$ ) and a team of elders (Acts 14:23; 1 Pet 5:1) to function as leadership of a particular church. Relations between leaders and their congregation members were a matter of utmost significance, and were expected to reflect love, honour, and respect (1 Thess 2:8; $5: 12,13)$. Some of the above approaches to leadership show similarities with how leadership was approached in the Biblical era. For example, Saul's traits such as charisma, physique, and war skills made him an appropriate leader of his time (1 Sam 10:23). Nehemiah tried to balance interpersonal relationships with the Jews from exile (Neh 2:17-19) and a task-oriented approach to leadership (Neh 2:5, 11-16) by facilitating 
the building of a temple for Yahweh. The leadership of Paul and of Jesus reflect some charismatic and transformational leadership traits when they become self-sacrificial (Acts 20:24; John 10:11, 15), and value deep change in their followers (Rom 12:2; 2 Cor 5:17).

However, the above social sciences approach to leadership should not simply be explicitly linked to how spiritual leadership should be practised within and beyond congregations. In the Bible, God was and is central to an appointment to leadership. For example, God appoints leaders for the sake of achieving his purpose of salvation (Moses, Ex 3:10; Paul, Acts 9:15) or punishment of those who disobey him (King of Assyria, Isa 10:7; 37:26-27; civil authorities, Rom 13:1, 4, 5). God prepares some people for leadership as early as in their mother's womb (Jer 1:5) or from eternity (Paul and his team of believers, 2 Tim 1:11; 1 Cor 4:9). Leadership is a gift God gives to people for the purpose of equipping others and building his church (Eph 4:11,12). God sometimes appoints more than one person as leader and expects them to work together with others as a team (Moses and Aaron, Ex 3:10; 4:16; 28:1; Jesus' apostles, John 6:70, 15:16; elders in the New Testament, Acts 20:28). Lastly; according to Breed (2016:2, 5), although leadership in congregations is accountable to God, it has the divine task to empower the laity to serve each other with their gifts so that they may live a holy life. Furthermore, while doing its duty, leadership in congregations must be motivated by their calling, not money or social pressure.

\section{The problem of overrating the minister and underrating the laity}

Even though the leadership in congregations knows that the Word of God insists that interaction between the leadership in congregations and the laity should reflect love, humility, and respect (1 Thess 2:8; 5:12, 13), the opposite often happens (Ez 34:1-10).

\subsection{The problem of overrating the minister}

For a long time, the practice of and studies on leadership have glorified, overrated, or overvalued the leader to such an extent that too many organisations and individuals aspire to leadership who should not (Grayson and Speckhart 2006:1; Burak and Bashshur 2013:1; Kritzinger 2007:13). In the context of South Africa, there are too many ministers of mushrooming churches who rise to leadership power. Many of them have neither been trained nor mentored; they are accountable to no-one. These ministers use lofty titles such as Man of God, Bishop, or Prophet. Some adopt academic titles such as Doctor or Professor even though they have no academic qualifications. According to Kritzinger (2007:11-13), overrating the minister in the congregation denotes a ministry characterised by a one-man show, where the minister is expected to lead and do everything, while the laity are simply receivers filling the gaps as far as possible. Kritzinger (2007:13) also argues that overrating the minister implies that the minister is on a higher level and more extraordinary than the laity. Hence, the minister is untouchable, infallible, and irreplaceable. In South Africa, the view of the minister as an extraordinary person has led to some ministers abusing their authority, feeding their members snakes and grass, encouraging their members to drink petrol, and spraying insecticide in the faces of their church members. These kinds of heinous acts by some ministers compelled the South African democratic government, through the Commission for the Promotion and Protection of the Rights of Cultural, Religious and Linguistic 
Communities (CRL), to raise concern about the appointment and integrity of some ministers of religion. Furthermore, overrating the minister implies that the church is a club for the clergy, where the interests of the ministers are discussed, and the laity are expected to comply with and adhere to them.

To maintain the overrating of some ministers in congregations, emphasis is placed on the hierarchy and strict control of the laity. For example, Kritzinger $(2007: 13,14,17)$ argues that hierarchy is maintained by ordination and title, which are assumed to make ministers extraordinary and distinguish them from the laity. Control over the laity is instituted through the abuse of the church order used to maintain the distinction between the laity and the minister, and authoritative privileges of the minister to administer sacraments. Overrating the minister is also promoted by encouraging the minister's unidirectional leadership influence, whereby congregation members are expected to passively receive this influence as part of their deference to the minister. Ministers who display unidirectional leadership influence often prefer lay people who are uncritical of and gullible to leadership practices.

Historically, how did ministers and laity interact in the church? Despite the potential usefulness of the laity, throughout history some ministers have underrated them in the church. Firstly, Ayres $(1962: 15,16)$ argues that some ministers viewed their laity as second-class citizens who tend to live dual lives, many of whom will not experience heaven. This kind of understanding was stronger at the time of the Western missionaries. Some ministers from mainline churches still adhere to the view that lay members who are less spiritual and live dual lives will not experience heaven.

Secondly, Ayres mentions that the hierarchy in the church classifies believers as: ministers, who are believed to have given their whole life to God; professional lay workers, who provide full-time service to the church; and lay people, who are illiterate and passive. I have observed that in the South African context, some of the mainline black African churches have a tradition of hierarchical differentiation of congregation members. Within the same congregation, some members wear a church uniform and belong to a specific guild, while others wear no church uniform and are just ordinary members of the congregation. Often the members who wear a church uniform and belong to a specific guild within a congregation are assumed more active and future leaders. They often receive more attention from the minister in terms of spiritual services as compared to the ordinary congregation members. My critical observation of the hierarchical differentiation of the congregation members as discussed above is that eventually it may lead to differentiation of congregation members, discrepancy in the relationship with congregation members, and undermining of some (ordinary) members as passive and ignorant.

Third and lastly, Russell $(1986: 58,59)$ argues that, in Luther's time, the laity were viewed as ritually unclean, illiterate, and ranked below the clergy. This was during the time when the Roman Catholic Church was the dominant church in Western Europe. Latin was used as the language of the scholarly and liturgy. The laity were ranked below the clergy because they were viewed as of the world and spiritually inferior. There were superstitions including that the laity were unclean and therefore not allowed to touch the sacraments. 


\subsection{From underrating to valuing lay people}

For a long time followers were denigrated, undermined or underrated in the practice of leadership (Grayson and Speckhart 2006:1). Followers who tried to resist this status quo were characterised as resistant, dysfunctional, illegitimate, lacking drive and ambition, and given names such as passive, conformers, and inferior (Bligh 2011:428; Gordon 2011:164-165, 167; Burak and Bashshur 2013:919, 920). According to Kritzinger (2007:13), underrating lay people in congregations turns them into spectators who cannot participate in the ministry, passengers who wait for the pastor to take them to their destination, and consumers who simply receive and consume whatever the minister gives them.

Scholars have identified a number of consequences of undermining followers in leadership. Grayson and Speckhart (2006:1) state that this leads to poor development of followers into leadership. For example, there are more followers than leaders, but hardly any attention is paid to the development of effective followers in terms of leaders development workshops. Kritzinger (2007:13) states that, due to their ignorance regarding empowering lay people, churches have a minimal impact on society. Active lay people express their gifts in organisations other than a church.

The emphasis on the distinction between a leader and a follower impedes the collaboration that should exist between a leader and a follower (Grayson and Speckhart 2006:1). Kritzinger $(2007: 13,14)$ blames this distinction on the ordination, the special regalia that ministers wear, and their privilege to administer the sacraments. This should be understood in a South African context whereby in some of the mainline churches, after ordination, a minister is vested with special regalia and authority to administer sacraments, which becomes the prerogative of the minister alone. Due to the shortage of ministers in some of the mainline churches, ministers have to travel long distances administering sacraments, which could also be done by the trained laity. In the long run the ministry of the Word and empowerment of the laity are adversely affected as ministers become ministers of sacraments and not ministers of the Word.

Studies on followership are still recent and growing, hence there is more literature about leadership than about followership (Grayson and Speckhart 2006:1). In the literature on leadership there are more theories and models on leadership than on followership (Grayson and Speckhart 2006:1). Why is there a need for more literature on followership? Because people are involved in leadership as either leaders or followers. For a leader to succeed in leadership, the co-operation and support of the follower is essential. But those in leadership often do not understand how to engage their followers so that leadership may attain the desired goal, hence leadership is sometimes ineffective or unsuccessful. In terms of congregations, believers are followers of Christ in the process of being developed into disciples of Christ. In Matthew 28:19, 20 Jesus commands us to make disciples of all nations and teach them to obey all the commands we have received from Him. Nowadays, ministers need to focus on helping congregation members to be authentic disciples of Christ and effective laity in the church of Christ.

In fact, lay people as followers of the leadership of the minister need to be valued as highly as the ministers, as they too are called into the service of God and the world. Like the ministers in the church, lay people are people of God and ministers of Christ. Therefore, no minister should be privileged over the laity, and no lay person should be undermined, because both ministers and the laity share in the ministry. For example, 1 
Corinthians 12:7 says each believer has received spiritual gifts which must be used to help one another. Lay people are responsible participants in the ministry of the church and mission of the Triune God by sharing leadership and obedience to those in leadership. As followers of the leadership in congregations, lay people must be empowered, equipped, and enabled to discover their own God-given talents and the vision to lead in their own contexts. Ayres $(1962: 15,18)$ argues that the lay person is an assistant, aide, partner, and a strengthening power to the minister.

Lay people must be viewed as agents of change, transformation, or renewal of the church and society. For transformation of the church and society to become authentic and powerful, lay people must be encouraged and developed to be the custodians and agents of this required change (Nel 2015:52). The worship service, workshops, retreats, and ward meetings must intentionally be used to empower lay people for service to renew the individual, the church, and society.

An educated, well-equipped, and developed lay person plays a significant role in the ministry of the church. According to Russell (1986:58), Luther encouraged learned lay people to play a critical role in the church such as holding church leadership accountable and contributing to the reform of the church. A learned lay person inspires a minister to acquire more skills and knowledge for further empowering the lay person. Eventually, an empowered lay person enriches leadership and contributes effectively in the ministry of the congregation. The lay person, in turn, develops confidence and trust in the minister concerning matters of the ministry.

Lay people are imitators of God and their ministers. Paul beseeched the Ephesians to be imitators of God in everything they do (Eph 5:1). This imitation of God can be observed in the humble service Jesus demonstrated to his disciples (John 13:15), and the interaction of the three persons in the Triune God. Paul pleads with the Corinthians to imitate him as he imitates Christ (1 Cor 11:1). Copan (2007:230,231) explains that on the one hand this Pauline imitation is implicitly linked to his Christocentric focus and fundamental virtues that flow out of Pauline understanding of Christ and his gospel. On the other hand, this Pauline imitation involves understanding Paul as an authentic and reliable follower of Christ who embodied in his thought and action the life of Christ he modelled for others. In short, lay people can be imitators of their master, Lord Jesus Christ, and imitators of the conduct of missionaries (2 Thess 3:7,9), the faith of spiritual guides (Heb 13:7), that which is good (3 John 11), and the apostle (1 Cor 4:16; 11:1; Eph 5:1; Heb 6:12).

\subsection{How should lay people and ministers interact in their leadership ministry?}

The interaction between ministers and lay people should be founded on the principle of the Triune God. Self-emptying, diversity, unity, and communal spirit are essential in order to avoid undermining each other and autocratic practices. According to Atkinson (2014:142, 143), the self-emptying process in the Triune God occurs as follows: The Father, in permitting the Son to be crucified, emptied himself in love and allowed the sword to pierce his soul (Luke 2:35). The Son was willing to undergo self-emptying by suffering the degradations and deprivations of earthly life. This self-emptying of the Son was not only for the salvation of humanity but also for the sake of the Father's glory (Phil 2:11) and the exaltation of the Holy Spirit in his earthly ministry (Luke 4:18; 11:20; 12:12; 24:49). The Holy Spirit at Pentecost self-emptied itself by entering the feeble and 
fallible human heart (Acts 2:4). Atkinson (2014:145) describes this interplay of selfemptying and exaltation as a manifestation of dynamic equality in the Trinity, whereby all three entities lower themselves in order to raise the others. For the leadership in congregations self-emptying implies that both ministers and lay persons must be able to sacrifice their personal interests and be willing to serve the other for the sake of the glory of God and the development of the other.

Diversity and unity coexist in the persons of the Triune God (Zscheile 2007:53-62). The uniqueness or the otherness should not be erased; it must be treasured and enhanced within the pattern of a larger unity. Within the Triune God, collaboration, sharing, and team spirit show a sense of community. In the context of a congregation, this implies that, even though ministers and the laity may have different gifts and responsibilities, these gifts and responsibilities must be used for the sake of developing each other and building the body of Christ.

God created humanity for a relationship with himself and other creations. After creating man (Gen 1:28), God commanded man to govern the earth and reign over all other creations. Thus, God expects humanity to sustain, protect, and care for the fauna, the flora, and the environment. Jesus stated that we should love God and our neighbour (Matt 22:37, 39). To love God, we need a deep change in terms of our feelings, decisions, thoughts, and actions so that they serve the will of God (Holladay 2008:43). To love our neighbour, we need to love everyone, one another, and those within our reach and beyond. We need to love as Jesus loves us and demonstrate acts of love. We must not allow our differences (Matt 5:43-44) and fears (Luke 10:30-36) to impede love for our neighbour. In our relationships, love should be the dominant value among other values such as justice and shalom. Most importantly, as humanity our relationships must be person-oriented more than task-oriented. For example, Jesus chose to meet the other person's need before fulfilling his daily tasks (Mark 5:21-43; 10:14; 6:37).

Furthermore, the interaction between ministers and the laity needs to demonstrate care (spiritual guidance and counselling), protection (from physical harm or death, false teaching, and slandering the image of the other), and feeding the flock (spiritual and natural knowledge acquired from the minister) (John 10:9-13; 21:15-17). Ministers must empower their laity with knowledge and skills so that the laity can move from where they are to where they ought to be. Before bodily leaving this earth, Jesus' final command was to go and make disciples (Matt 28:19). Hence, lay people need to be helped to be authentic disciples of Jesus. In order to be a disciple, the lay person needs a personal relationship with God and the minister. Regular interaction between the lay person and the minister is required for learning by observing, listening, and participating in everything the minister does, until the lay person has learnt to discover, develop, and use their God-given abilities (Adeyemo 2006:1223).

\section{Types of followers (laity)}

Depending on the context, leadership can generally be classified as bad or good leadership, or effective or ineffective leadership. Followers can also be classified as effective or ineffective followers. According to D'Souza (2001:75), effective followers are active, take initiative, participate, go beyond their expected duty, and are ready to apply their talents. Nelson and Quick $(2006: 406,407)$ state that effective followers show self-management and responsibility. Despite their commitment to organisations such as 
the church, they are willing to invest in their own development to make an impact on their ministry. In the face of challenges, they are courageous, honest, and willing to offer constructive criticism to leadership.

By contrast, ineffective followers are passive and need prodding and constant supervision, because they tend to avoid responsibility, and always look to leaders to do the thinking (D'Souza 2001:75). In terms of the congregation, lay people can be classified into two groups: those who are controlled by the desires of the flesh and display hostile, selfish, and conflicting attitudes towards leadership, and those who bear the fruits of the Holy Spirit such as love, peace, and self-control (Gal 5:19-22).

\subsection{The power of followers in leadership}

The shift in the epistemology and practice of leadership indicates that both the leader and the follower possess power and influence in leadership. For a long time, ineffective followers have tolerated the practice of bad and ineffective leadership, to the detriment of organisations and the destructive influence on followers. Hence, Bligh (2011:431) relates that followers can be implicated in bad, destructive leadership, even though they may have the right to resist such leadership. Bligh $(2011: 430,431)$ argues that followers have a new role to play, namely to actively counteract the effect of destructive and toxic leaders by holding leaders accountable and creating term limits and departure terms. This means that followers no longer need to be passive; they have a choice to actively participate in constructing or resisting vision of the leader. Followers are also responsible to participate in solving societal issues in the world such as dictatorship, corrupt government, and corporate abuse of power. In Scripture, although the laity have to obey and respect their leaders, they are required to obey them only in matters that honour God (Acts $4: 18,19,20)$. The lay people have the right and the responsibility to refuse to obey their leaders if they transgress the will of God (Dan 3:13-18).

\subsection{Sources of power for followers}

Leaders have power which they may derive from various sources such as their position, the resources under their control, and their charming personality. In Scripture, leaders and the laity derive their power from God (Acts 1:8) who dispenses different spiritual gifts through his Holy Spirit (1 Cor 12). Hence, both leaders and followers have power. Despite the Holy Spirit being a source of power for the laity, D'Souza (2001:174) states that the other source of power for the laity may be the possession of skills and resources which the congregations and the ministers value. The personal history of the laity relates to their achievements and unassailable contributions to the leadership and the congregation, and their straightforwardness in speaking the truth, as noted in leadership. In the light of the above, ministers should be able to identify learned and effective laity whose God-given talents can be used in the ministry.

\section{The situation in the Dutch Reformed Church in Africa (DRCA) Free State (FS)}

The DRCA was established for black Africans and is one of the historical family members of the Dutch Reformed (DR) family of churches in South Africa such as the Dutch Reformed Church (DRC, for the Afrikaners), the Reformed Church in Africa (RCA, for the Indians), and the Dutch Reformed Mission Church (DRMC, for the mixed 
race $)^{4}$ (DRCA OFS 2003:7). According to Crafford (1982:149, 158, 173, 245, 564), prior to 1994, the DRCA had eight regional synods, including the DRCA FS. In 1994 the DRCA experienced a schism and was left with two synods, namely the DRCA FS and the DRCA Phororo ${ }^{5}$ (NGKA [s.a.]). In 2010 the DRCA Northern and Southern Transvaal ${ }^{6}$ Combined Synod, and in 2015, the DRCA Eastern Cape Synod were revived. At present the DRCA has four regional synods. This study will focus on the congregations of the DRCA FS regional synod.

\subsection{Theology of leadership in the DRCA FS}

In the DRCA the essence of spiritual leadership is centred in Christ, the Son of God. The Son is the incarnate leader who modelled to human beings how to exercise spiritual leadership. Christ is the Lord and head of the universal church (Col 1:18); the source of all leadership in the church, the maintainer, the final and ultimate leader of his church (Rev 1:8). The Holy Spirit empowers and sustains the spiritual leadership in the congregations. The Father manifests his leadership through our Lord Jesus Christ (Matt 28:19; Eph 1:22; Col 1:28; 1 Cor 15:25).

The DRCA believes that Christ manifests his leadership for our salvation in his church in three ways, namely as a prophet, a priest, and a king (Thuto ya Bokreste 1987:59). These three offices of Christ in the DRCA form the basis for doing ministry of the church. They are adopted from the Old Testament and it is believed that Christ fulfilled and renewed them for the development of his church. In truly confessing Christ as their Lord, believers (both the minister and the congregation members) adopt or inherit these three functional roles of Christ (Thuto ya Bokreste 1987:58). Believers are prophets with Christ when they truthfully proclaim God to the world and defeat the Devil (Grudem 2011:630; Thuto ya bokreste 1987:59). They are priests with Christ when they can offer themselves as a living spiritual sacrifice to God (1 Pet 2:5-9; Rom 12:1). They are kings with Christ, because they share in his reign (Eph 2:6) and in his authority (Eph 6:10-18). They have been promised that they shall reign forever with Christ (Rev 22:5).

In the leadership structure of the DRCA, including the DRCA FS, these functions of Christ are linked to the offices of the church. According to Buka ya kereke (1986:150, $152,154)$, from a theological point of view, the minister adopts the role of a prophet, whereby they are expected mainly to witness about the Word of God in relation to the present and the coming of the Holy Spirit (John 14:26), parousia (John 14:2, 3), and Christ's death, burial and resurrection (Matt 16:21). The minister as prophet needs to contribute towards transforming the existing evil structures by challenging the status quo among the people of God and the nations. The minister's chief duty in the DRCA FS is to preach the Gospel, empower believers, administer the sacraments, and help with the management and administration of the congregation. From a theological point of view, the deacon adopts a priest's role, thereby collecting alms offered in the church, ensuring quality service to and worship of God, offering prayers and praises to God on behalf of

\footnotetext{
It was disbanded in 1994 when a large part of the DRCA merged with the DRMC to form the Uniting Reformed Church in Southern Africa (URCSA).

5 The DRCA Phororo is a regional synod in the North West and Northern Cape and is mainly dominated by the Tswana tribe.

6 Transvaal was a province during the apartheid era in South Africa. The new names of provinces in this region are Gauteng, Limpopo and Mpumalanga.
} 
the people, and serving as an agent of love, reconciliation, and charity. In the DRCA FS the deacon is mostly responsible for collecting and distributing alms for charity and comforting those in need of priestly service. From a theological point of view, the ruling elder adopts a king's role and is expected to maintain peace, justice, and divine rule. In short, the elder's duties in the DRCA FS is to oversee and manage the congregation, as well as maintain order and discipline. Besides their specific duties in the DRCA FS, elders and deacons are also expected to preach and empower others with the Word within and beyond the congregation borders.

A critical reflection on the above discussion reveals that in the DRCA FS every believer is called for a specific purpose which they need to fulfil within a specific context and the leadership in congregations is responsible to empower the laity for specific purposes according to their calling (DRCA OFS 2003, Article 4). This implies and concurs with the premise that congregation members are also leaders, but they are required to exercise their leadership in different spheres of society such as the family, the church, and their workplace. For example, in playing their prophetic, priestly, and kingly roles, they must proclaim the Gospel and confront injustice, offer prayers and alms to those in need, and strive for divine rule both in church and society.

Secondly, theologically in the DRCA FS a minister is called to perform the role of a prophet. According to the DRCA OFS (2003:18), in addition to a prophet's role, the minister is also expected to perform some of the priestly and kingly duties. Kritzinger (2007:11, 12) challenges this kind of practice when he asks why ministers should be given the privilege of administering the sacraments while other lay leaders could administer them with minimum training and guidance. The other concern Kritzinger raises, is that sacraments are valued more than the Word to such an extent that a minister becomes a minister of the sacraments and not of the Word. This is true in the context of the DRCA FS, because some ministers are so preoccupied with administering sacraments that they ignore the value of empowering the laity with the Word. According to Pali (2016:138-140), Bible studies, the practice of intensive prayer to God, the fellowship of believers, and the empowerment of the laity for mission and diaconia are experiencing a serious decline. At the same time, because there is a shortage of ministers, ministers are described as being too busy, overburdened with ministerial duties such as administration and management, and conflicts are reportedly escalating out of control. I have observed that some ministers tend to micromanage when delegating responsibilities to their laity, thus overburdening themselves unnecessarily with duties not their own.

Lastly, I have also observed that, according to the theology of leadership in the DRCA FS, elders could and should be empowered to deal with the management of congregations and to exercise leadership in the church councils, presbyteries, and synods. This would give ministers more time to study the Word and equip themselves for empowering their laity. Regrettably, the majority of ministers do not trust the leadership of their laity such as elders in the church councils, presbyteries or synods, stating that they do not have enough learning and may develop pride and undermine them as ministers. This has resulted in some ministers occupying too many leadership positions at the various levels of the church structure to such an extent that they do not have time for their own ministerial duties. 


\section{Contemporary situation in the DRCA FS}

The DRCA FS is one of the largest regional synods of the DRCA; in 2019 it had 34 ministers with 152 congregations (DRCA General Synod 2019:96). This means that currently more than three quarters of the congregations in the DRCA FS do not have ministers. According to the most recent DRCA FS report (2015:49) and Pali (2016:142, 327), a shortage of ministers and too many ministerial duties have caused some ministers to suffer from exhaustion and depression. A shortage of ministers has also increased tension in the relationships between ministers and their congregations, because some ministers are unable to fulfil their duties as expected by the members of their congregations. A shortage of ministers and too many congregations have compelled ministers to be available, especially in interim congregations, for specific duties only, such as administering the sacraments, and weddings or funerals, leaving no time for the empowerment of their laity to discover their God-given potential.

According to Pali $(2016: 97,348)$, ministers do not have much time available to equip their congregation members for the internal and external ministry of the church. Those who equip their congregation members do it mainly for the internal ministry of the congregation. As a result, the external ministry of the congregations of the DRCA FS has suffered a serious decline for over two decades. Empowering lay people in the internal ministry of the congregations does not help a great deal, as the vast majority of the ministers, focus on issues such as the administration of finances, leading worship services, church polity, and the role of the members of the church councils.

\subsection{Interaction between ministers and their laity in the congregations of the DRCA FS}

This discussion mainly draws from part of the quantitative data - Congregational Survey (CS) and Minister Survey (MS) - and qualitative data - Individual Interviews with ministers (II) and Focus-Group Interviews with congregation members (FGI) - in the DRCA FS of Pali (2016:76-152).

\subsubsection{Relationship and trust ${ }^{7}$}

Before I discuss how ministers and congregation members view each other, it is wise to explore the issue of relationship as surveyed by Pali $(2016: 127,135)$ or discussed in some of the assemblies of the DRCA FS Synod. According to Pali's (2016:127, 135) ministerial survey (MS), 55\% of the participant ministers viewed trust as important; $86 \%$ of them viewed cordial relationships with congregation members as important; $79 \%$ of them were satisfied with their relationships with their own congregational leaders; and $83 \%$ of the participant ministers mentioned that they were also satisfied with their relationships with other ministers in the DRCA. Furthermore, 94\% of the participant ministers felt that members of the congregations did care about them, while $63 \%$ of the participant ministers mentioned that they did not experience stress when their congregational members criticised them. From this quantitative data, one can deduce that the majority of the ministers value trust and relationships as important and that the relationships between ministers and congregation members seem to have been on a satisfactory level and on friendly terms prior to 2015. But, according to Pali's (2018:3) 
article on analysis of conflict situations in the congregations of the DRCA FS, relationships between ministers and their laity seem to be declining due to conflicts. What actually happened?

The schism ${ }^{8}$ in 1994 and the settlement ${ }^{9}$ reached in 2011 had severe consequences for both the URCSA and the DRCA. However, the DRCA FS as the bigger regional synod among those still left in the DRCA, was most affected. After the schism, the DRCA FS was left financially bankrupt, with a declining mission and diaconial ministry, and a reduced number of ministers leaving more than half of the congregations without ministers. According to the Moderamen (DRCA FS 2015:49), this led to ministers being overburdened with too many ministerial responsibilities; some became ill and suffered exhaustion and psychological drain. As a result, some ministers could not fulfil their ministerial duties. This gradually led to increasing tension and conflict between ministers and the members of their congregations. The report of the Moderamen of the DRCA FS (2015:20-24, 39-43) indicates that over half of the presbyteries complained, on several occasions, about unresolved conflicts in the congregations and among ministers. According to Pali (2018:4, 7, 11), for more than two decades, and particularly between 2015 and 2018, the DRCA FS has experienced increasing conflicts ranging from disagreements, verbal insults, and physical violence to litigation. The ministers are blamed for the majority of these conflicts and accused of failure to interpret the church order appropriately and favouritism, particularly regarding disciplining only some of those in leadership and some members of their congregations.

\subsubsection{How ministers and laity view each other within the DRCA FS}

The schism in the DRCA, including the DRCA FS, left both ministers and congregation members like a wounded, bruised and frustrated lion because its young ones were taken away. The DRCA FS never recovered from the schism. Post-1994 the DRCA FS Synod (DRCA OFS 1999:26) agreed to promote evangelists to be ministers upon completion of a two-year certificate course at the University of the Free State (UFS). This brought temporary relief to ministers, but also challenges. The majority of the evangelists were already old and resistant to change, thus placing them in conflict with the young people. The difference in qualifications between evangelists who became ministers, and ministers who already had higher qualifications than the evangelists, resulted in some disparities between them. Some of the evangelists who became ministers were ridiculed and some congregation members and ministers viewed them as being of poor quality (Anonymous letter to the Moderamen of the DRCA FS 2019:2). On the other hand, some of the ministers with higher qualifications than the evangelists were viewed as arrogant and domineering in their approach to ministry and leadership.

8 In 1994 an agreement was reached to unite the DRCA (for the black Africans) and the DRMC (for the mixed race) to form URCSA. Two of the DRCA regional synods (DRCA FS and DRCA Phororo) withdrew from URCSA citing transgression of church order protocol concerning unity. This withdrawal from URCSA led to litigation and disputes over property and legitimacy of the DRCA, which the DRCA won in court (Case number. 536/96) (NGKA s.a.).

9 After the DRCA won this court case in 1996, disputes between the DRCA and URCSA continued. An intervention by the DRC in 2011 led to the formation of a panel to prepare a settlement between the two churches which led to financial compensation for congregations that had lost property to buy land and build their own church buildings (DRCA FS 2015:19, 25-31). 
The mere fact that ministers differentiate themselves according to qualifications set a precedence for differentiation of ministers and their laity. It is evident from the qualitative data of Pali (2016:112-123) that participant ministers viewed the members of their congregations in two ways. The positive perspective is that congregation members have the responsibility to hold church leadership accountable for their actions and decisions. This implies that congregation members need not be silent when confronted with injustices, immorality, and corruption within and beyond the congregation. Congregation members need to understand their faith and their responsibility to support their congregations and its leadership through their physical presence, prayer, and financial support. It should also be noted that, in this instance, the majority of the participant ministers ${ }^{10}$ agreed that the members of their congregations are capable of fulfilling their duties, because they are well trained in their responsibilities. Those who transgress the church order are disciplined.

However, other participant ministers ${ }^{11}$ described their congregation members as critical, but also destructive in their approach. This is usually the case when congregation members use the church order or information they gathered to destroy others in the congregation. One minister stated that the members of his congregation do not understand their faith; hence they are passive and resistant to knowledge. Other ministers raised their concern about members' lack of obedience and resistance to obeying orders from the leadership. The majority of the ministers with a negative view of their congregation members also claimed that these members are incapable of meeting their responsibilities, because they lack vision and honesty in their ministries.

Most of the participant congregation members ${ }^{12}$ from the qualitative data described these positive expectations of their ministers: to be caring, supporting, approachable, humble, protecting, and exemplary. Others mentioned that ministers must be able to communicate well, share, and be able to witness the Word of God to those within and beyond the congregations, and administer the sacraments. However, other congregation members ${ }^{13}$ held a negative view of their ministers, denoting them as disastrous, autocratic, and destructive, and displaying poor leadership that is rude, arrogant, unapproachable, and full of mistakes. A number of congregation members mentioned poor relationships with their ministers as a result of members' distaste for issues such as their ministers' immorality, lack of integrity, and not being exemplary. Hence, the majority of these despondent congregation members described their relationships with their ministers as characterised by a lack of trust, suspicion, and disrespect.

In summary, my thorough analyses of the qualitative data of Pali (2016:112-123) revealed that ministers who reflected a negative perception of their congregation members mostly adhere to a pastoral leadership ${ }^{14}$ framework. Similarly, the laity of these ministers (who adhere to pastoral leadership and described their laity in negative terms) also gave a negative description of their ministers. But ministers who reported a more positive view of their congregation members, adhere to other leadership frameworks

\footnotetext{
Data from II.

Data from II.

2 The congregation members of six of the eight participating congregations gave a positive description of their ministers. Data from FGI.

13 The majority of the members from two of the participating congregations. Data from FGI.

14 The working definition of pastoral leadership used, is leadership that is committed to a personal relationship with the followers, in order to show care, to guide, and to be present in times of need (D'Souza 2001:41-44).
} 
such as servant and transformational leadership. In general, the members of the congregations of these ministers associated themselves with the leadership of their ministers, thus emphasising the positive aspects of their ministers' leadership.

\section{Leadership experience}

The qualitative ${ }^{15}$ research done by Pali (2016:122-123) also asked both the ministers and the congregation members a question as to how they experience leadership in the DRCA FS congregations. The way in which leadership is experienced, can motivate or demoralise believers. Five of the eight participant ministers from II indicated that they experience leadership in a positive manner, especially in their congregations. Three of the eight participant ministers from II reported negative experiences of leadership. For example, one minister stated that leadership in his congregation is passive. Leaders do not use their initiative, but rather expect the minister to tell them what to do. Another minister mentioned that he experiences leadership in the congregation as characterised by division and conflicts. Another minister reported a lack of respect and co-operation as part of his leadership experience in the congregation. In their response, the majority of the congregation members from the congregations of the above-mentioned five positive ministers agreed that they have a positive experience of leadership, although some leaders still need to improve. On the other hand, the majority of the congregation members from the congregations of the above-mentioned three ministers who reported negative experiences stated that they experience leadership as characterised by division and lack of respect.

In both sets of interviews ${ }^{16}$ the majority of the participants reported a positive experience of the leadership in their congregations even though in some congregations signs of festering relationships between ministers and congregation members were becoming a cause for concern. This cause for concern became a reality in 2015 when the Moderamen of the DRCA FS (2015:20-24, 39-43) reported serious conflict situations in many ${ }^{17}$ of the congregations of the DRCA FS, resulting in more intense conflict situations thereafter, especially beyond 2015 and the present.

\section{Conclusion}

The research question of this article is: What are the dynamics of the interaction between the ministers and the congregation members in the DRCA FS? According to Pali's Minister Survey (Pali 2016:127, 135) as discussed above, the interaction was mainly positive, as there was trust, and relationships between the ministers and members of the congregations were valued. However, the qualitative data from Pali (2016:115-116), the report of the DRCA FS Moderamen (2015:19-24, 32), and the research of Pali on the analysis of conflict situations within the leadership of the DRCA FS $(2018: 1,2)$ suggest otherwise. For example, qualitative data (II, FGI) from Pali $(2016: 148,342)$ indicates that in some congregations, tension and serious conflicts were brewing between some ministers and members of their congregations. The report of the DRCA FS Moderamen

\footnotetext{
Read both Focus-Group Interviews and Individual Interviews of ministers, question 7.

Read both Focus-Group Interviews and Individual Interviews of ministers, question 7.

Pali (2016:214) mentions that in 17 presbyteries of the DRCA FS more than half of the presbyteries lodged complaints with the DRCA FS 2015 synod. Most of the complaints were about conflicts in congregations that the presbyteries and ministers in congregations failed to resolve.
} 
(2015:19-24, 32; 2019:21-27) confirmed these tense situations in congregations when the report raised concern about lack of co-operation, lack of respect, lack of obedience to church authority, and lack of trust between some ministers and their congregations. Further research by Pali $(2018: 1,2)$ indicates that from 2015 to the present the relationships between those in leadership and some of the ministers and their laity became so tense that serious conflict erupted in many congregations of the DRCA FS. The sources of these conflicts include favouritism, misinterpretation of the church order, and laity resisting initiatives in the ministry. The qualitative data of Pali (2016:113, 115, 148) shows that the main source of this tension between ministers and their laity is a domineering approach by leadership, especially pastoral leadership: ministers know, while the members must simply wait, obey and follow the minister. The report of the Moderamen of the DRCA FS Synod (2015:32) indicates that the sources of tension in relationships between ministers and the members of their congregations include pride, poor relations, lack of respect, and abuse of authority.

Reading the report of the DRCA FS Moderamen (2015:19-24, 32, 2019:21-27) and Pali (2018:1,2), the interaction between ministers and their laity in the congregations of the DRCA FS, especially from 2015 period, displayed a relationship of lack of trust, suspicion, and disrespect. But towards the end of 2018, things seemed to take a positive turn when the Moderamen of the DRCA and several efforts at intervention by the DRC in the FS and the General Synod of the DRCA called for repentance and reconciliation in the congregations of the DRCA FS (DRCA FS 2019:24, 29, 48-55). However, it seems that these interventions in 2018 did not achieve the desired result as the report of the Moderamen of the DRCA FS (2019:21-27) indicates that conflict situations still pervade congregations of the DRCA FS and the DRCA FS is now faced with potential schism.

Some suggestions to be taken into serious consideration are as follows: There is a need for deep theological reflection on spirituality and ministry of leadership within the congregations of the DRCA FS. The Moderamen of the DRCA FS (2015:32) raised the concern that there is a need for self-introspection regarding lack of order, respect for each other and fear of God amongst those in leadership in congregations of the DRCA FS. There is a need for analysis of the legacy of white imperialist practices in the context of the legacy of apartheid and white missionaries within the ministry of the leadership in the DRCA FS. For example, since the withdrawal of white ministers and financial assistance from the DRC, ministry and leadership practices within the DRCA FS struggle to cope and to sustain the integrity of the church. Kritzinger (2011:118) mentions that the DRCA (FS) was financially and theologically dependent on the DRC for a long time, and this affected its ministry and critical relationship with the Dutch Reformed family of churches. White imperialist practices affected spirituality, culture, and relationships among black Africans (Gordon 2002:10-13; Buntu 2013:2). Deep reflection on the above-mentioned suggestions will help gain understanding of the complexity of the practical problems in the interactions among those in DRCA FS congregations. Furthermore, it will lead to a process of reviewing and rethinking the interaction of ministers and the laity in the practice of ministry within congregations of the DRCA FS. 


\section{BIBLIOGRAPHY}

Adeyemo, T. 2006. Discipleship. In Adeyemo, T. (ed.), Africa Bible commentary: A one volume commentary written by 70 African scholars. Nairobi: WordAlive Publishers, p. 1223.

Anonymous letter to the Moderamen of the DRCA FS. 2019. DRCA FS. [n.p.] Atkinson, W.P. 2014. The trinity and servant-leadership, Evangelical Review of Theology 38(2): 138-150.

Ayres, F.O. 1962. The ministry of the laity. A Biblical exposition. Philadelphia, PA: Westminster Press.

Bass, B. and Bass, R. 2008. The Bass handbook of leadership: Theory, research and management applications. ( $4^{\text {th }}$ ed.). New York: Free Press.

Blackaby, H. and Blackaby, R. 2011. Spiritual leadership: Moving people onto God's agenda. (Revised and expanded). Nashville, TN: B \& H Publishing Group.

Bligh, M. 2011. Followership and follower-centred approaches. In Bryman, A., Collinson, D. and Grint, K. (eds), The Sage handbook of leadership. London: Sage, pp. 425-436.

Bligh, M.C. and Meindl, J.R. 2005. The cultural ecology of leadership. In Messick, D.M. and Kramer, R.M., Psychology for leaders: Using motivation, conflict, power to manage more effectively. Mahwah, NJ: Lawrence Erlbaum Associates, pp. 11-28.

Bolden, R. 2011. Distributed leadership in organizations: A review of theory and research, International Journal of Management Reviews 13:251-269.

Breed, G. 2016. The diakonia of the elder according to 1 Peter, In die Skriflig 50(3):19. Available online: http://dx.doi.org/10.4102/ids. v50i3.2102. (Accessed 1 December 2019)

Buka ya kereke. 1986. NGKA. Wellington: CLF.

Buntu, B.A.O. 2013. Claiming self: The role of Afrikology in social transformation,

Scriptura 112: 1-12. Available online: https://doi.org/10.7833/112-0-62. (Accessed 1 December 2019)

Burak, O.C. and Bashshur, M.R. 2013. Followership, leadership and social influence, Leadership Quarterly 24(6):919-934.

Copan, V.A. 2007. Saint Paul as spiritual director. An analysis of the concept of the imitation of Paul with implications and applications to the practice of spiritual direction. Milton Keynes: Paternoster.

Crafford, D. 1982. Aan God die dank. Pretoria: NG Kerk-boekhandel.

DRCA OFS. 1999. Agenda of the DRCA OFS Synod. Thaba Nchu: [s.n.].

DRCA OFS. 2003. Church Order. Bloemfontein: [s.n.].

DRCA FS. 2015. Agenda of the DRCA FS Synod. Steynsrus: [s.n.].

DRCA FS. 2019. Agenda of the DRCA FS Synod. Klerksdorp: [s.n.].

DRCA General Synod. 2019. Agenda of the DRCA General Synod. Barkley-West: [s.n.]

D'Souza, A.A. 2001. Leaders for today. Hope for tomorrow: Empowering and empowered leadership. Nairobi: Paulines Publications Africa. 
Gangel, K.O. 2006. Christian leadership. In Horton, D. (ed.), The portable seminary: A master's level overview in one volume. Bloomington, MN: Bethany House, pp. 590-609.

Grudem, W. 2011. Systematic theology: An introduction to Biblical doctrine. (2 $2^{\text {nd }}$ ed.). Nottingham: Intervarsity Press.

Gordon, R.D. 2010. Dispersed leadership: Exploring the impact of antecedent forms of power using a communicative framework, Management Communication Quarterly 24(2):260-287.

Gordon, J.U. 2002. African leadership in the 20 ${ }^{\text {th }}$ century: An enduring experience in democracy. Lanham: University Press of America.

Gordon, R.D. 2011. Leadership and power. In Bryman, A., Collinson, D., Grint, K., Jackson, B. and Uhl-Bien, M. (eds), The Sage handbook of leadership. London: Sage, pp. 195-203.

Grayson, D. and Speckhart, R. 2006. The leader-follower relationship: Practitioner observations, Leadership Advance Online, 4:1-6. Available online:

http://www.regent.edu/acad/sls/publications/journals/leadershipadvance/issue6/pd f/grayson_speckhart.pdf.

Grint, K. 2011. A history of leadership. In Bryman, A., Collinson, D., Grint, K., Jackson, B. and Uhl-Bien, M. (eds), The Sage handbook of leadership. London: Sage, pp. 3-14.

Grudem, W. 2011. Systematic theology: An introduction to Biblical doctrine. (2 $2^{\text {nd }}$ ed.). Nottingham: Intervarsity Press.

Hellriegel, D., Slocum, J.W. (Jr) and Woodman, R.W. 1998. Organisational behaviour. ( $8^{\text {th }}$ ed.). Cincinnati, $\mathrm{OH}$ : South-Western College Publishing.

Holladay, T. 2008. The relationship principles of Jesus. Wellington: Lux Verbi.

Huizing, R.L. 2011. Bringing Christ to the table of leadership: Moving towards a theology of leadership, The Journal of Applied Christian Leadership 5(2):58-75.

Kritzinger, J.J. 2007. Rethinking ministry, new wine in new wine skins. Wellington: CLF.

Kritzinger, J.J. 2011. Die einde van sending: Fases in die sending bedryf, Acta

Theologica 31(2):111-134. Available online: https://doi.org/10.4314/actat.v31i2.6. (Accessed 1 December 2019)

Nel, M. 2015. Identity-driven churches. Who are we, and where are we going? Wellington: Biblecor.

Nelson, D. and Quick, J.C. 2006. Organisational behaviour: Foundations, realities and challenges. $\left(5^{\text {th }}\right.$ ed.). Mason, $\mathrm{OH}$ : Thomson South-Western.

NGKA. s.a. Available online: www.ngka.co.za/ngka. (Accessed 28 January 2016)

Northouse, P.G. 2012. Introduction to leadership concepts and practice. (2 ${ }^{\text {nd }}$ ed.). London: Sage.

Pali, K.J. 2016. Leadership and transformation in the African church: A practical theological study of one denomination. Unpublished DPhil dissertation, University of the Free State, Bloemfontein, and Vrije Universiteit, Amsterdam.

Pali, K.J. 2017. Theological reflections on the ministerial challenges of the DRCA OFS in the post-apartheid South Africa, Hervormde Theological Studies 73(2):1-12. 
Pali, K.J. 2018. An analysis of conflict situations within the leadership and various structures of the Dutch Reformed Church in Africa, Orange Free State, HTS Theological Studies 74(2):1-11.

Russell, P.A. 1986. Lay theology in reformation. Popular pamphleteers in Southwest Germany 1521-1525. Cambridge: Cambridge University Press.

Steers, R.M., Porter, L.W. and Bigley, G.A. 1996. Motivation and leadership at work. ( $6^{\text {th }}$ ed.). New York: McGraw-Hill.

Thuto ya Bokreste [Catechism book of the DRCA].1987. Bloemfontein: NGK SendingUitgewers.

Wright, W. 2009. Introduction: Mentor to mentor. In Jacobsen, E.O. (ed.), The three tasks of leadership. Grand Rapids, MI: W.B. Eerdmans, pp. 1-16.

Yukl, G. 2002. Leadership in organisations. (5 ${ }^{\text {th }}$ ed.). Upper Saddle River, NJ: PrenticeHall.

Zscheile, D.J. 2007. The Trinity, leadership, and power, Journal of Religious Leadership 6(2):43-63. 